\title{
Postharvest calcium chloride treatments do not help to increase shelf-life of bananas
}

Antenette Niranjala Perera, Anjani Manjulika Karunaratne*

Department of Botany, Faculty of Science,

University of Peradeniya, Sri Lanka

anjanikarunaratne@yahoo.com

* Correspondence and reprints

Fruits, 2002, vol. 57, p. 87-94 (C) 2002 Cirad/EDP Sciences All rights reserved

DOI: $10.1051 /$ fruits:2002008

Resumen Español, p. 93

\section{Postharvest calcium chloride treatments do not help to increase shelf-life of bananas.}

Abstract - Introduction. Calcium chloride $\left(\mathrm{CaCl}_{2}\right)$ treatment has been shown to increase the shelf-life of fruits, mainly through making cell walls less accessible to pathogens and softening enzymes. Materials and methods. Bananas of four cultivars ['Ambon' (AAA), 'Embul' (AAB), 'Kolikuttu' (AAB) and 'Seenikehel' (ABB)] were dipped in or pressure infiltrated with $4 \% \mathrm{CaCl}_{2}$. To determine the effect of exogenous ethylene on treated fruits, they were ripened with exogenous ethylene. $\mathrm{Ca}^{2+}$ in cell wall fractions were monitored by atomic absorption spectrophotometry. Cup plate assays were performed to determine pectinase activity. Results and discussion. Pressure infiltration accelerated ripening and disease, and reduced firmness $(P<0.05)$. However, when exposed to ethylene, $\mathrm{CaCl}_{2}$ pressure-infiltrated bananas were insignificantly firmer than distilled water-infiltrated and ethylene-ripened bananas, showing a significant interaction $(P<0.05)$ between infiltration treatments and ethylene ripening. There was no consistent increase in covalently bound pectin of cell walls as seen in fruits that respond positively to $\mathrm{CaCl}_{2}$. Firmness reduction and ripening acceleration by $\mathrm{Ca}^{2+}$ treatment cannot be explained if polygalacturonase (PG) (known to be inhibited by $\mathrm{Ca}^{2+}$ ) was the dominant pectinase. Enzyme assays gave evidence of PG activity. When ammonium oxalate (known to bind $\mathrm{Ca}^{2+}$ ) was eliminated from the test medium, pectinase activity increased with increasing $\mathrm{pH}$ ( $\mathrm{pH} 5$ to 9). The presence of a pectinase enzyme which exhibits activity in the presence of $\mathrm{Ca}^{2+}$ is apparent. Conclusion. $\mathrm{Ca}^{2+}$ does not appear to influence cell wall structure of bananas but appears to influence ripening physiology.

Sri Lanka / Musa (fruits) / storage / calcium chloride / postharvest physiology / postharvest decay / polygalacturonase

\section{Le traitement au chlorure de calcium après récolte ne permet pas d'augmenter la durée de conservation des bananes.}

Résumé - Introduction. Le traitement au chlorure de calcium $\left(\mathrm{CaCl}_{2}\right)$ permettrait d'augmenter la durée de conservation des fruits, principalement en rendant les parois cellulaires moins accessibles aux organismes pathogènes et aux enzymes de ramollissement. Matériel et méthodes. Les bananes de quatre cultivars ['Ambon' (AAA), 'Embul' (AAB), 'Kolikuttu' (AAB)

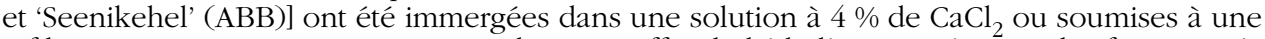
infiltration sous pression avec cette solution. L'effet de l'éthylène exogène sur les fruits traités a été testé lors de leur mûrissement. La présence de $\mathrm{Ca}^{2+}$ dans des fragments de paroi cellulaire a été suivie par spectrophotométrie en absorption atomique. Des analyses ont permis de déterminer l'activité des pectinases. Résultats et discussion. Les infiltrations sous pression ont accéléré la maturation et le développement de maladies, et ont diminué la fermeté $(P<0,05)$. Cependant, exposées à l'éthylène, les bananes infiltrées sous pression avec du $\mathrm{CaCl}_{2}$ ont été aussi fermes que celles mûries sous éthylène et traitées à l'eau distillée ; il existerait donc une interaction significative $(P<0,05)$ entre les traitements d'infiltration et le mûrissement sous éthylène. Il n’y a eu aucune augmentation réelle en pectines liées en covalence comme il est trouvé dans les fruits qui répondent positivement au traitement à $\mathrm{CaCl}_{2}$. La réduction de fermeté et l'accélération de la maturation par traitement au $\mathrm{Ca}^{2+}$ ne peuvent être expliquées si la polygalacturonase (PG) (connue pour être inhibée par $\mathrm{Ca}^{2+}$ ) est la pectinase dominante. Les titrages de l'enzyme ont mis en évidence une activité de la PG. En éliminant du milieu testé l'oxalate d'ammonium (connu pour lier $\mathrm{Ca}^{2+}$ ), l'activité des pectinases a augmenté en même temps que le $\mathrm{pH}$ ( $\mathrm{pH} 5$ à 9). La présence d'une enzyme pectinase qui se révèle active en présence de $\mathrm{Ca}^{2+}$ est apparente. Conclusion. $\mathrm{Ca}^{2+}$ ne semble pas influencer la structure des parois cellulaires de bananes mais agirait sur la physiologie de maturation.

Sri Lanka / Musa (fruit) / stockage / chlorure de calcium / physiologie après récolte / maladie post récolte / polygalacturonase 


\section{Introduction}

Compounds of calcium $\left(\mathrm{Ca}^{2+}\right)$ have shown promise in quality retention of fruits and vegetables primarily through maintaining firmness and decreasing storage rots [1]. The ability of $\mathrm{Ca}^{2+}$ ions to bind with mainly pectic acids in cell walls forming cation cross bridges is believed to make cell walls less accessible to softening enzymes and to cell wall degrading enzymes of pathogens [2]. Calcium chloride $\left(\mathrm{CaCl}_{2}\right)$ has been reported to delay the onset of ripening in tomato [3], mango [4] and avocado [5].

The present experiments were designed based on preliminary findings [6]. Dip treatments carried out on 'Embul' bananas with (2, 4, 6 and 8) \% $\mathrm{CaCl}_{2}$ solutions showed no significant effect on peel colour or disease. In addition, treating 'Embul' bananas with $4 \% \mathrm{CaCl}_{2}$ solutions by dips, pressure infiltration or vacuum infiltration did not help to increase shelf-life by delaying either peel colour development or disease. As reports are available where the response varies with application technique and with different cultivars of a same genus, the present study was to investigate the effect of different application techniques of $\mathrm{Ca}^{2+}$ on bananas of four local cultivars and to initiate preliminary investigations to seek an explanation for the results obtained.

\section{Materials and methods}

\subsection{Plant material}

Fresh fruits of cultivars 'Ambon' (AAA), 'Embul' (AAB), 'Kolikuttu' (AAB) and 'Seenikehel' (ABB) were used at harvesting maturity. No pre- or postharvest fungicide treatments were applied. When fully yellow fruits were required, they were allowed to ripen to the required colour scale. Only the first two hands (highest grade) in a bunch were used. All experiments were performed and fruits stored in ambient conditions [i.e., room temperature $=(28 \pm 2){ }^{\circ} \mathrm{C}$, relative humidity $=(65 \pm 5) \%]$.

\subsection{Experimental design}

Fruits were obtained so that at least four banana suckers were represented in a single treatment of a trial. Fruits on a hand were assigned to different treatments randomly as already described [7]. When using different cultivars, 20 to 30 fruits from a single cultivar were used in a single trial.

For firmness determination, sixteen 'Embul' banana fruits of equal size, representing four different suckers, were taken. A nested design was used where bananas infiltrated with either distilled water or $\mathrm{CaCl}_{2}$ were nested in ethylene treatment, and planned comparison of means were carried out [8] using the SAS computer package (version 6), Cary, USA, by determining a priori contrasts of $\mathrm{CaCl}_{2}$-treated and control bananas ripened naturally or with ethylene. Two to four trials were done in the above experiments.

For cell wall fractionation, a total of forty 'Embul' bananas was used; the experiment was repeated for two sets. For the crude enzyme preparation of the cup plate assay, a total of twenty 'Embul' bananas was used.

\subsection{Calcium chloride treatments}

Fruits were treated by either dipping or pressure infiltrating in $\mathrm{CaCl}_{2}$. A $4 \%$ solution of $\mathrm{CaCl}_{2}(\mathrm{w} / \mathrm{v})$ was made from powder of calcium chloride, dihydrate (Fluka Chemica) in distilled water, and $0.1 \%$ Triton $\times 100$ (BDH) $\left(50 \mu \mathrm{L} \cdot \mathrm{L}^{-1}\right)$ was added as a surfactant. The solution made up fresh was used only once for dipping (20 min) or pressure infiltration. Pressure infiltration was accomplished by dipping fruits in the solution and applying pressure $\left(4.2 \times 10^{3} \mathrm{~kg} \cdot \mathrm{m}^{-2}\right)$ for $2 \min [7]$.

Peel colour and disease were scored daily for each fruit. For assessing peel colour, a colour scale (CS) of 1 to 5 (with CS-1: dark green and CS-5: yellow) was used, and a scale of 1 to 7 allowed the assessment of disease [7].

\subsection{Fruit firmness}

Fruits were pressure infiltrated with either $4 \% \mathrm{CaCl}_{2}$ or distilled water. They were 
divided into two equal groups. One group was ripened by exposure to exogenous ethylene $\left(100 \mu \mathrm{L} \cdot \mathrm{L}^{-1}\right.$ for $\left.24 \mathrm{~h}\right)$ and, after reaching CS-5 (about 5 days), firmness was recorded by using a hand-held penetrometer (Forestry Suppliers Inc., UK) [7].

\subsection{Levels of $\mathrm{Ca}^{2+}$ in fractions of cell wall material}

A set of 'Embul' bananas was either pressure infiltrated with $4 \% \mathrm{CaCl}_{2}$ or left untreated. The peel and pulp (50 g each, separately, representing all bananas in a treatment) tissues were taken for analysis from five bananas per treatment from each colour scale (CS-1, $24 \mathrm{~h}$ after treatment, and of CS-5 within $24 \mathrm{~h}$ of reaching CS-5).

Tissues were cut into cubes $\left(2^{3} \mathrm{~mm}^{3}\right)$ and lyophilised. The cell wall was fractionated into its various components using the anhydrous cell wall material (1 g) where a series of extractions and concentrations by lyophilisation were done to obtain soluble free pectins (SFP), ionically-associated pectins, covalently bound pectin, hemicellulosic and cellulosic fractions, and were subjected to wet digestion followed by atomic absorption spectrophotometry (Atomic Absorption/Emission Spectrophotometer GBC 904AA) [9].

\subsection{Enzyme assay}

A crude enzyme extract was prepared as already described [10]. Samples (200 g each) of peel and pulp were homogenised separately in cold $\left(18{ }^{\circ} \mathrm{C}\right)$ acetone $(200 \mathrm{~mL})$ in a wareing blender ( $5 \mathrm{~min}$ ). The homogenate was centrifuged $(1000 \mathrm{~g}, 10 \mathrm{~min})$ and the supernatant was discarded. The residue was washed $(\times 2)$ to remove any acetone solubles by repeated centrifugation and resuspension in cold acetone. The acetone insoluble crude cell wall material was dried in a Buchner funnel lined with Whatman No. 4 filter paper by passing an air current, scraped out of the filter paper and stored at $18^{\circ} \mathrm{C}$. This was reconstituted in $0.1 \mathrm{M}$ phosphate buffer.

Cup plate assay [11] was used to estimate pectinase activity modified as already described [10]. The sterile test medium in petri plates contained 1\% sodium polypectate (substrate), $0.5 \%(\mathrm{w} / \mathrm{v})$ ammonium oxalate and $2 \%$ agar, in appropriate buffer solution $(100 \mathrm{~mL})$ to obtain a $\mathrm{pH}$ range of 5 to 9; $0.1 \mathrm{M}$ phosphate buffer ( $\mathrm{pH}$ 5-6); $0.1 \mathrm{M}$ Tris-HCl (pH 7-9). These plates were used to estimate polygalacturonase (PG) activity of crude enzyme extract and standard PG (Sigma), separately. The same method was used to estimate pectinase activity again, by eliminating ammonium oxalate from the medium, known to bind with bivalent cations including $\mathrm{Ca}^{2+}$.

\section{Results}

\subsection{Fruit firmness}

In pressure-infiltrated and dipped bananas of all cultivars, peel colour and disease development hastened (results not shown). The reduction in firmness of bananas pressure-infiltrated with $\mathrm{CaCl}_{2}$ was significant $(P<0.05)$ but, when ripened by exposure to ethylene, $\mathrm{CaCl}_{2}$-treated bananas were insignificantly firmer (figure 1). A significant interaction $(P<0.008)$ was observed between infiltration treatments

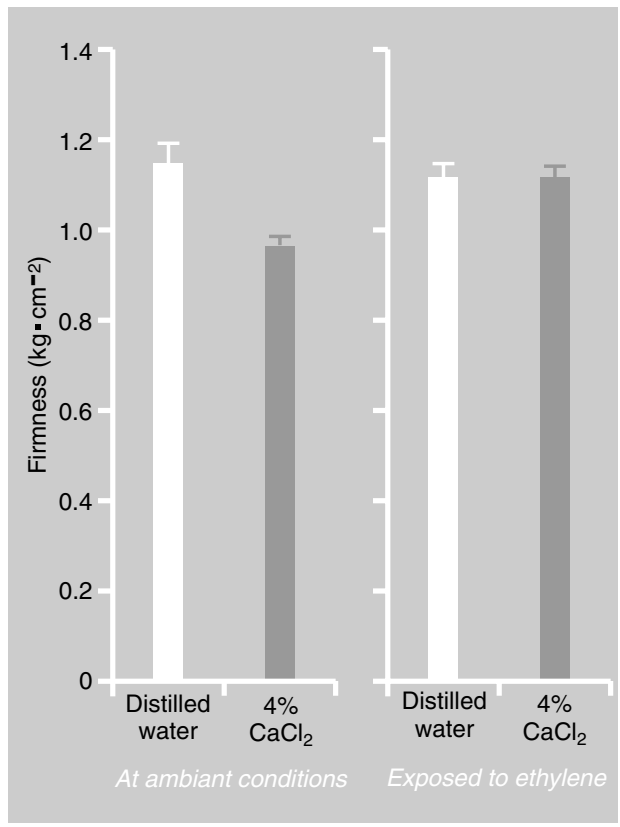

Figure 1.

Firmness of bananas pressure infiltrated with $4 \% \mathrm{CaCl}_{2}$ and ripened at ambient conditions or by exposing to ethylene, as compared to controls pressure infiltrated in distilled water, and probability levels of a-priori contrasts significant at $P=0.05$. 


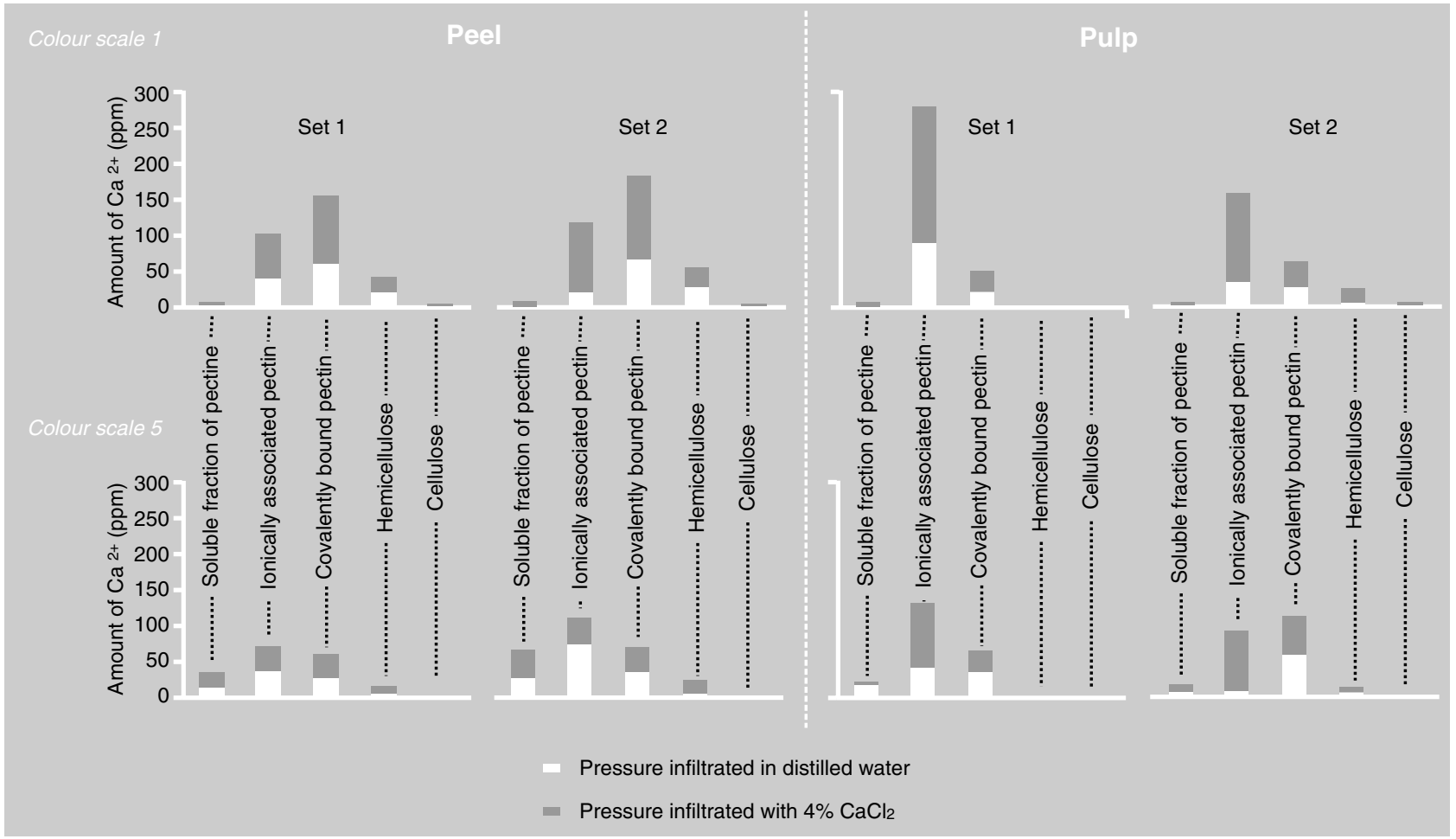

Figure 2.

Amount of $\mathrm{Ca}^{+2}$ in different fractions of cell wall material of peel and pulp of two sets of untreated control and $4 \%$ $\mathrm{CaCl}_{2}$-infiltrated bananas at colour scales 1 (dark green) and 5 (yellow). and ethylene ripening. The following $a$-priori contrasts were significant $(P<0.05)$ : $\mathrm{CaCl}_{2}$-treated ethylene-ripened bananas versus $\mathrm{CaCl}_{2}$-treated bananas ripened naturally $(P=0.020)$, ethylene-ripened control versus $\mathrm{CaCl}_{2}$-treated bananas ripened naturally $(P=0.029)$ and $\mathrm{CaCl}_{2}$-treated bananas ripened naturally versus control ripened naturally $(P=0.02)$ (figure 1$)$.

\subsection{Levels of $\mathrm{Ca}^{2+}$ in fractions of cell wall material}

Calcium was present in all fractions of cell wall material irrespective of treatment (figure 2). Both ionically associated pectins (IAP) and covalently bound pectins (CBP) were of the highest magnitude. At CS-1, $\mathrm{Ca}^{2+}$ levels were generally higher in the treated bananas and, at CS-5, they were variable except in IAP of pulps. Both CS-1 and $\mathrm{CS}-5$ recorded higher levels of IAP in treated pulps. The CBP of treated bananas was slightly higher only in the peel at CS-1.

\subsection{Enzyme assay}

The decrease in activity of pectinase extract with increasing ambient $\mathrm{pH}$ was comparable to the decrease in activity of standard polygalacturonase (figure 3). When pectinase activity was determined by eliminating ammonium oxalate, a tendency towards increasing enzyme activity with increasing $\mathrm{pH}$ values was observed (figure 3).

\section{Discussion}

A $4 \% \mathrm{CaCl}_{2}$ solution was used as many investigators have used this concentration and obtained positive results. The present study gave discouraging results with the $\mathrm{CaCl}_{2}$ treatment to all four cultivars of banana studied in spite of the fact that these four cultivars of bananas had varying physicochemical characteristics such as fruit firmness, peel thickness and [peel:pulp] ratios [12]. 


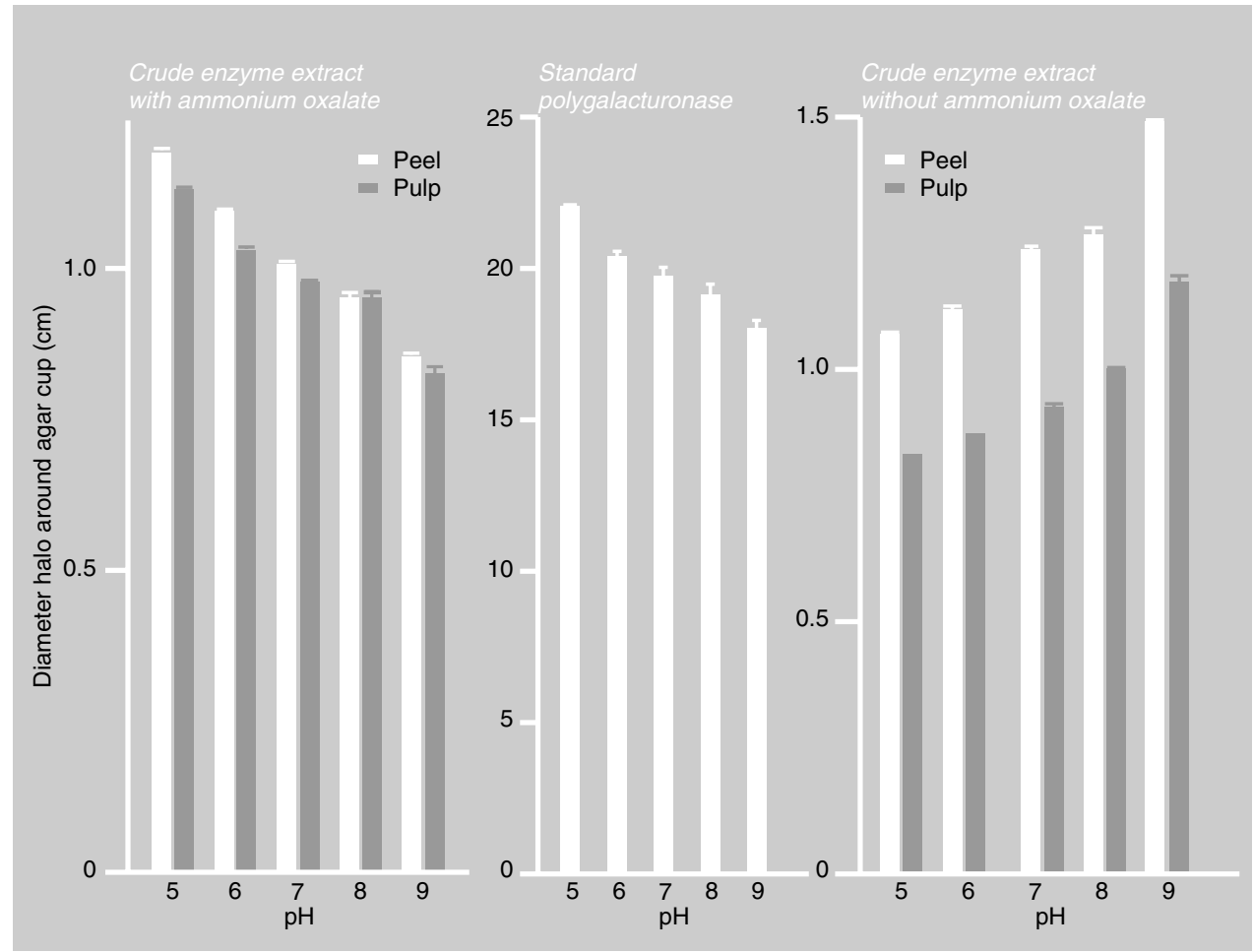

Studies done by other investigators also indicate that postharvest application of $\mathrm{Ca}^{2+}$ accelerated ripening of cultivars of banana, 'Cavendish' [13] and 'Robusta' [14]. The hastened colour development may be linked to faster achievement of senescence leading to shorter shelf-life. A previous study on these four cultivars of banana showed a tendency towards negative correlation (without statistical significance) of lesion diameters of anthracnose and fruit firmness [12]. These results appear to suggest that firmness reduction observed in $\mathrm{Ca}^{2+}$-treated bananas may increase tendency to susceptibility to anthracnose and, hence, reduction of shelf-life. In an attempt to compare the direct effect of the $\mathrm{CaCl}_{2}$ treatment in the absence of the structural barrier of the fruit skin, a control experiment was carried out using identical peel disks cored out of banana and apple, a fruit which is known to benefit from the treatment. The range of $\mathrm{Ca}^{2+}$ ions sorbed by disks of banana and apple were, respectively, (16-21)\% and (10-15)\% of the external solution [6]. However, while the treated disks of apple appeared firmer to the touch after treatment, those of banana were softer (unpublished data of A.N. Perera).

It is reported that $\mathrm{Ca}^{2+}$ may have an important role in ethylene generation during fruit senescence [15]. Therefore, the significant reduction in firmness in $\mathrm{Ca}^{2+}$ treated bananas kept at ambient conditions may be attributed to this role of $\mathrm{Ca}^{2+}$ (figure 1). The present results on firmness also appear to strengthen an earlier hypothesis that a temporary ethylene treatment sufficient to stimulate ripening in banana fruit tissue partly suppresses endogenous ethylene production [16]. In the present study, the effect of firmness reduction by the $\mathrm{Ca}^{2+}$ treatment was not observed when fruits were ripened with exogenous ethylene, probably because both treated and control fruits depended directly on the same source of exogenous ethylene resulting in the same level of firmness.

Covalently bound pectin (CBP) and flesh firmness were reported to have a direct positive relationship [9]. Pectins are
Figure 3.

Pectinase activity at increasing $\mathrm{pH}$ levels, determined by the diameter of halo in cup-plate assays, in crude enzyme extract with ammonium oxalate, standard polygalacturonase and crude enzyme extract without ammonium oxalate (bananas). 
attached to celluloses and hemicelluloses by covalent bondings; therefore, for maintenance of cell wall structure, CBP are considered to be more important than IAP and application of $\mathrm{CaCl}_{2}$ would result in the maintenance of a higher amount of $\mathrm{Ca}^{2+}$ in CBP [17]. There was no evidence of such a trend in the present study (figure 2).

Pectinase enzymes such as $\alpha$-glucosidases [18], endo and exo polygalacturonase and galactosidases [19] were reported in ripening bananas. Polygalacturonase activity is known to be inhibited by $\mathrm{CaCl}_{2}$ [20]. Galactosidase activity in apples was shown to decrease when treated with $\mathrm{CaCl}_{2}$ [21]. If the roles of galactosidases and polygalacturonase were prominent, a reduction in ripening with treatment would have been observed. The optimum peaks for activity of $\alpha$-glucosidases were reported to be $\mathrm{pH} 4.5$ and 6.5 [18] which is contrary to the gradual change of activity within a larger $\mathrm{pH}$ range observed in the present study (figure 3).

On the other hand, activity of pectate lyase (PL) is reported to be dependent upon divalent cations, particularly $\mathrm{Ca}^{2+}[22]$. PL is known to have an absolute requirement for $\mathrm{Ca}^{2+}$ [23]. Clones with homology to PL are reported to be particularly abundant in banana pulp, and this suggests a significant role for PL activity in wall disassembly during ripening in the pulp [24]. The increasing enzyme activity seen in the present study with increasing $\mathrm{pH}$ (figure 3c) may be an indication of PL activity in banana tissue, although this is not a pectinase often found in fruits.

The present preliminary investigations appear to suggest that, in banana, the role of $\mathrm{Ca}^{2+}$ in cell wall cross bridging is insignificant but evidence of $\mathrm{Ca}^{2+}$ interference with the ripening physiology is apparent.

\section{Acknowledgements}

We gratefully acknowledge: Grant No. E-2110 from the International Foundation for Science, Sweden, Dr. D.S.A. Wijesundera and Dr. S. Samita for statistical advice,
Prof. P.A.J. Perera and Dr. Susil Silva for help extended in calcium analysis, Ms. Shyama Deegala for skilled technical assistance.

\section{References}

[1] Poovaiah B.W., Glenn G.M., Reddy A.S.N., Calcium and fruit softening, Physiol. Biochem. Hortic. Rev. 10 (1988) 107-152.

[2] Stow J., Effect of calcium ions on apple fruit softening during storage and ripening, Postharvest Biol. Tec. 3 (1993) 1-9.

[3] Wills R.B.H., Tirmazi S.I., Effect of calcium and other minerals on ripening of tomatoes, Aust. J. Plant Physiol. 6 (1979) 221-227.

[4] Tirmazi S.I.H., Wills R.B.H., Retardation of ripening of mangoes by postharvest application of calcium, Trop. Agr. 58 (1981) 137-141.

[5] Wills R.B.H., Tirmazi S.I., Inhibition of ripening of avocados with calcium, Sci. Hortic. Amsterdam 16 (1982) 323-330.

[6] Perera O.D.A.N., A study of the physicochemical characteristics of banana and response to postharvest acid and calcium treatment, Univ. Peradeniya, M. Phil. thesis, Sri Lanka, 2000.

[7] Perera O.D.A.N., Karunaratne A.M., Response of bananas to postharvest acid treatments, J. Horti. Sci. Biotech. 76 (1) (2001) 70-76.

[8] Sokal R.R., Rohlf F.J., Biometry, the principles and practice of statistics in biological research, 3rd, Ed. W.H. Freeman and Co., New-York, USA, 1995.

[9] Siddiqui S., Bangerth F., Effect of pre-harvest application of calcium on flesh firmness and cell wall composition of apples-influence of fruit size, J. Hortic. Sci. 70 (2) (1995) 263-269.

[10] Dharmasiri M.A.N., A study of papaya anthracnose caused by Colletotrichum gloeosporioides (penz) Sacc. and C. Capsici (Syd) with special reference to its latent phase, Univ. Peradeniya, thesis, Sri Lanka, 1998.

[11] Dingle J., Reid W.W., Solomons G.L., The enzymic degradation of pectin and other polysaccharides. 11. Application of the "Cup Plate" assay to the estimation of enzymes from fungal pathogens, J. Sci. Food Agr. 4 (1953) 149-155.

[12] Perera O.D.A.N., Basnayake B.M.K.M.K., Karunaratne A.M., Physicochemical charac- 
teristics, popularity and susceptibility to anthracnose of some local banana cultivars, J. Nat. Sci. Found. Sri Lanka 27 (2) (1999) 119-130.

[13] Wills R.B.H., Tirmazi S.I., Scott K.J., Effect of postharvest application of calcium on ripening rates of pears and bananas, J. Hortic. Sci. 57 (4) (1982) 431-435

[14] Huddar A.G., Chandramonti H.D., Nachegowda V., Effect of postharvest application of calcium on ripening of bananas cv. Robusta, Haryana J. Hortic. Sci. 20 (1991) 60-64.

[15] Tanaka K., Yokota M., Takno Y.I., Asakura T., Miyairi K., Okuno T., Role of calcium in fruit involved in ethylene production, Actua Hortic. 197 (1998) 227-236.

[16] Vendrell M., McGlasson W.B.. Inhibition of ethylene production in banana fruit tissue by ethylene treatment, Aust. J. Biol. Sci. 24 (1971) 885-895.

[17] McCann M.C., Wells B., Roberts K., Direct visualization of cross-links in the primary plant cell wall, J. Cell Sci. 96 (1990) 323-334.

[18] Konishi Y., Kitazato S., Asano R., Nakatani $\mathrm{N}$., Polymorphism of acid and neutral-glucosidases in banana pulp: changes in apparent pls and affinity to Con A of enzymes during ripening, Agr. Biol. Chem. Tokio 55 (4) (1991) 1089-1094.
[19] Markovic O., Heinrichova H., Lenkey B., Pectilytic enzymes from banana, Collect. Czech. Chem. Commun. 40 (1975) 769-774.

[20] Biggs A.R., El-Kholi M.M., El-Neshawy S., Nickerson R., Effects of calcium salts on growth, polygalacturonase activity and infection of peach fruit by Monilinia fructicola, Plant Dis. 81 (4) (1997) 399-403.

[21] Siddiqui S., Bangerth F., Differential effect of calcium and strontium on flesh firmness and properties of cell walls in apples, J. Hortic. Sci. 70 (6) (1995) 949-953.

[22] Cooper R.M., Rankin B., Wood R.K.S., Cell wall degrading enzymes of vascular wilt fungi. 11. Properties and modes of action of polysaccharidases of Verticillium alboatrum and Fusarium oxysporum f. sp. Iycopersici, Physiol. Plant Pathol. 13 (1978) 101-134.

[23] Guevara M.A., Gonzalez-Jaen M.T., Estevez P., Multiple forms of pectic lyases and polygalacturonase from Fusarium oxysporum f. $\mathrm{sp}$. radicis lycopersici: regulation of their synthesis by galacturonic acid, Can. J. Microbiol. 43 (3) (1997) 245-253.

[24] Medina-Suarez R., Manning K., Fletcher J., Aked J., Bird C.R., Seymour G.B., Gene expression in the pulp of ripening bananas, Plant Physiol. 115 (1997) 453-461.

\section{El tratamiento postcosecha con cloruro de calcio no permite aumentar la duración de conservación de los bananos.}

Resumen - Introducción. El tratamiento con cloruro de calcio $\left(\mathrm{CaCl}_{2}\right)$ permitiría aumentar la duración de conservación de los frutos, principalmente haciendo que las paredes celulares sean menos accesibles a los organismos patógenos y a las enzimas de reblandecimiento. Material y métodos. Se sumergieron cuatro cultivares de banano ['Ambon' (AAA), 'Embul' (AAB), 'Kolikuttu' (AAB) y 'Seenikehel' (ABB)] en una solución de $\mathrm{CaCl}_{2}$ al $4 \%$ o se sometieron a una infiltración a presión con esta solución. Se probó el efecto del etileno exógeno en los frutos tratados durante su maduramiento. La presencia de $\mathrm{Ca}^{2+}$ en unos fragmentos de pared celular fue seguida mediante espectrometría de absorción atómica. Unos análisis permitieron determinar la actividad de las pectinasas. Resultados y discusión. Las infiltraciones a presión aceleraron la maduración y el desarrollo de enfermedades y disminuyeron la firmeza $(P<0.05)$. Sin embargo, expuestos al etileno, los bananos infiltrados a presión con $\mathrm{CaCl}_{2}$ mostraban la misma firmeza que los madurados bajo etileno y tratados con agua destilada; existiría pues una interacción significativa $(P<0.05)$ entre los tratamientos de infiltración y el maduramiento con etileno. No hubo ningún aumento real de pectinas en enlace covalente tal y como se encuentra en los frutos que responden positivamente al tratamiento con $\mathrm{CaCl}_{2}$. $\mathrm{La}$ reducción de firmeza y la aceleración de la maduración por tratamiento con $\mathrm{Ca}^{2+}$ no pueden explicarse si la poligalacturonasa (PG) (conocida por ser inhibida por $\mathrm{Ca}^{2+}$ ) es la pectina 
dominante. Los titulados de la enzima evidenciaron una actividad de la PG. Al eliminar del medio probado el oxalato de amonio (conocido por enlazar $\mathrm{Ca}^{2+}$ ), la actividad de las pectinasas aumentó al mismo tiempo que el $\mathrm{pH}$ ( $\mathrm{pH} 5$ a 9). La presencia de una enzima pectinasa que se revela activa en presencia de $\mathrm{Ca}^{2+}$ es evidente. Conclusión. $\mathrm{Ca}^{2+}$ no parece influenciar la estructura de las paredes celulares de los bananos pero actuaría sobre la fisiología de maduración.

Sri Lanka / Musa (frutas) / almacenamiento / cloruro cálcico / fisiología postcosecha / enfermedades postcosecha / poligalacturonasa

To access this journal online: www.edpsciences.org 